\title{
Validation of Nitrogen Fertilizer Recommendation for Cotton at Middle Awash Areas, Afar Region
}

\author{
Diriba Megersa Soboka ${ }^{1} \quad$ Bethel Nekir $^{2} \quad$ Mekuria Bekele $^{3} \quad$ Getinet Adugna $^{4}$ Zeyede Aregahegn ${ }^{5}$ \\ Werer Agricultural Research Center, Ethiopian Institute of Agricultural Research, EIAR \\ P.O.Box 2003, Werer, Ethiopia, Corresponding author's
}

The research is financed by Ethiopian Institute of Agricultural Research, EIAR

\section{Abstract}

The productivity of Cotton, the cash crop in middle awash has been declined due to the deteriorated productivity of soil from miss-management of soil fertility and irrigation water that causes salinity problems. Additionally, application of the optimum rate of the most yield-limiting nutrient, nitrogen fertilizer for cotton varieties is still limiting. This experiment was conducted during 2017-2018 to validate the best and significant results of previously conducted experiments, on larger plots in similar agro-ecology and soil type at Gewane and Amibara districts of the Afar region, Ethiopia. The recommended Nitrogen fertilizer (46 kg ha-1) and farmer practice (no fertilizer) were replicated thrice per farmers' field across four experimental sites. Pre-sowing composited and after harvest treatment-wise soil samples were collected and analyzed following the standard procedures. The seedcotton yield of the field experiment was subjected to analysis of variances using the SAS software program version 9.0. Analysis of variance for combined data over the years and locations reveals that plant height was significantly influenced by locations and also the interaction effects of year-location. In terms of seed-cotton yield, a significant difference was observed due to the effects of locations and treatments applied. Consequently, a significantly higher mean seed-cotton yield ( 2.89 ton ha $^{-1}$ ) was recorded at $46 \mathrm{~kg} \mathrm{ha}^{-1}$ of Nitrogen fertilizer level over the local practice (without fertilizer) 1.72 ton ha-1 of seed-cotton yield. Therefore, $46 \mathrm{~kg} \mathrm{ha}^{-1}$ of nitrogen fertilizer is identified as a better management option for cotton production in middle Awash.

Keywords/Phrases: Cotton, Middle-Awash, nitrogen, validation, yield-limiting nutrient

DOI: $10.7176 / \mathrm{JNSR} / 10-8-02$

Publication date: April $30^{\text {th }} 2020$

\section{Introduction}

Cotton (Gossipium hirsutum) is a cash crop in different parts of Ethiopia as well as in the middle Awash, Amibara areas (Abebe, 1982). Over $64 \%$ of the total seed-cotton production of the country was produced from this area (Ethiopian Investment Agency, EIA, 2012). However, the productivity of the soil has been declined and deteriorated due to the irrigation condition and salinity problem in the area (Worku and Bedadi, 2016). Thus, the soil of this area is deficient in essential nutrients mainly Nitrogen (Worku and Bedadi, 2016). Nitrogen fertilizer is the most yield-limiting nutrient in all crops other than carbon and hydrogen, because of its requirement by plants in the greatest quantity (Roy et al., 2006). Similarly, in the middle-awash valley of Ethiopia, from the three primary nutrients required for healthy plant growth (Nitrogen, Phosphorus and Potassium, NPK), PK are not responsive on cotton yield, except the nitrogen fertilizer (Adugna et al., 2016;Menaleshewa et al., 2016).

Even though the optimum nitrogen application plays a major role in determining a wide range of seed-cotton yield and growth parameters (Gari et al., 1989; McConnell et al., 1996; Saleem et al., 2010), at Amibara and its surroundings, optimum rate of nitrogen fertilizer application for cotton varieties are still limiting. The recent experiment on nitrogen fertilizer requirement for the cotton crop at Werer Agricultural Research Center under five different nitrogen levels $\left(0,23,46,69\right.$ and $92 \mathrm{~kg} \mathrm{ha}^{-1}$ ) from 2004 to 2005 (Adugna et al., 2016) and during 2009 (Ayissaa and Kebede, 2011) have got convincing results. Nevertheless, validation was not conducted to a greater number of farmers on similar agro-ecology and soil type. That is why this experiment was conducted to validate the best and significant results in larger plots on similar agro-ecology and soil type.

\section{Materials and methods}

\subsection{Location}

The experiment was conducted on three farmers' field of Gewane and Amibara districts, Afar region, Ethiopia, during 2017-2018 main-cropping seasons. The study areas are geographically located between $9^{\circ} 20^{\prime} 0$ " $\mathrm{N}$ and $10^{\circ} 34^{\prime} 0^{\prime \prime} \mathrm{N}$ latitude and $40^{\circ} 8$ '0" E and 40 49'0" E longitude (Figure 1.) with altitude of $740 \mathrm{~m}$.a.s.l. The average annual rainfall of the area is $593 \mathrm{~mm}$, and the average maximum and minimum temperatures of the study area are $34^{\circ} \mathrm{C}$ and $19^{\circ} \mathrm{C}$, respectively. 


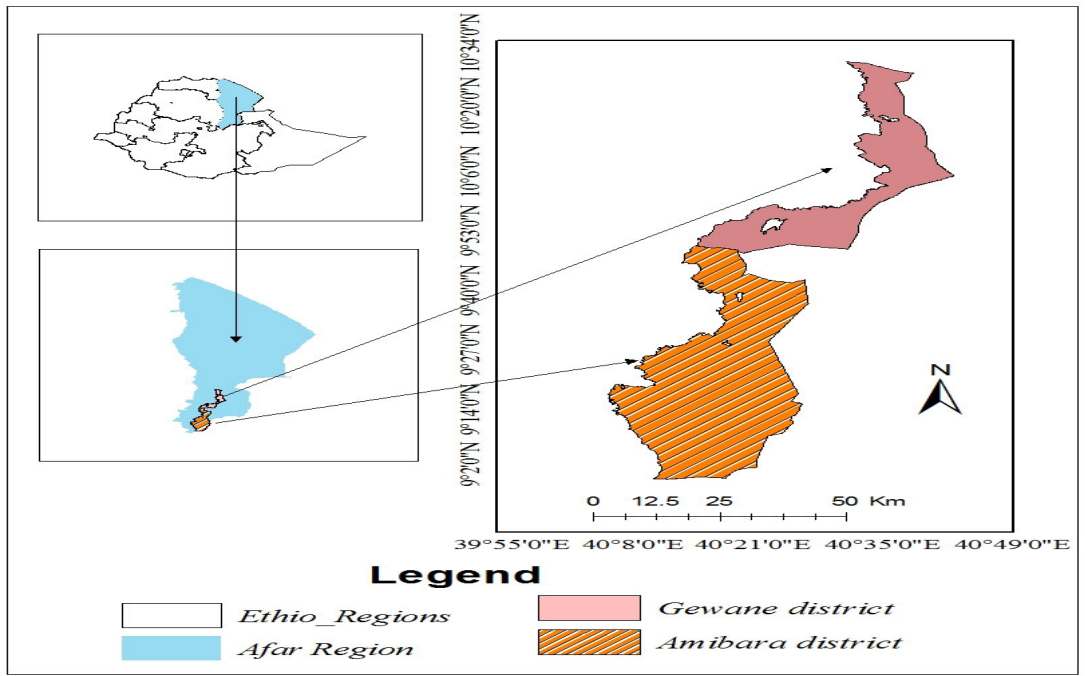

Figure 1: Location map of the study site of Gewane and Amibara districts

\subsection{Treatments setup}

The recommended nitrogen fertilizer $\left(46 \mathrm{~kg} \mathrm{ha}^{-1}\right)$ and farmer practice (none-fertilizer) were replicated thrice per farmers' field across all four experimental sites with $10 \mathrm{~m} * 10 \mathrm{~m}$ plot size. As well as, the plant spacing was $20 \mathrm{~cm}$ and $90 \mathrm{~cm}$ intra and inter-row spacing respectively with net harvestable plot size of $72.9 \mathrm{~m}^{2}(9 \mathrm{~m} * 8.1 \mathrm{~m})$ comprising nine harvestable rows. The common practices including agronomic activities, fertilizer application and other crop management practices those recommended for cotton production were uniformly applied to all plots. Additionally, well adapted Deltapine-90 cotton variety was used for the trial.

\subsection{Data collection and analysis}

\subsubsection{Soil data collection}

A composited soil sample was collected from the experimental plots in each study sites before planting and for each treatment after harvest at 0-30 $\mathrm{cm}$ soil depth. The chemical compositions of the soil samples were analyzed at the Soil Laboratory of Werer Agricultural Research Center following standard procedure. Soil $\mathrm{pH}$ and electrical conductivity (EC) using 1:1 soil to water ratio were measured from a solution of saturated paste extract by $\mathrm{pH}-$ meter (Peech, 1986). Organic matter was determined using Walkley and Black wet-oxidation method (Walkley and Black, 1934) and the total N by Kjeldahl procedure (Bremner, 1996). Available phosphorous was determined following the Olsen method (Olsen et al., 1954) after extraction with sodium bicarbonate solution (pH 8.5). The soil textural classes were similar (Table 1) across all locations (silt loam) except Werer site (silty clay loam).

Table 1: Soil textural classes of the locations before sowing

\begin{tabular}{lcccc}
\multicolumn{1}{c}{ Location } & Clay (\%) & Sand (\%) & Silt (\%) & Textural classes \\
\hline Werer & 32 & 12 & 56 & silty clay loam \\
Bedul-ale & 14 & 28 & 58 & silt loam \\
Bedehamo & 20 & 28 & 52 & silt loam \\
Gewane & 22 & 26 & 52 & silt loam \\
\hline
\end{tabular}

\subsubsection{Crop yield data collection}

Total seed cotton yield was collected at first and second picking and the total sum was weighed (gram/plot) and converted to ton per hectare for statistical analysis.

\subsubsection{Statistical analysis}

The seed-cotton yield of the field experiment was subjected to analysis of variances using SAS software program version 9.0 (SAS Institute, 2003). Significant differences between treatment means was compared and separated using the least significant difference (LSD).

\section{Results and discussion}

\subsection{Soil and seed-cotton yield results}

The soil samples from Bedehamo, Bedul-ale and Gewane kebeles have relatively higher $\mathrm{pH}$ values and higher Electrical conductivity (ECe). Whereas, soil samples from Werer have relatively less alkaline as compared to the three sites. Electrical conductivity values of the three sites (Bedehamo, Bedul-ale and Gewane) show that these sites have relatively high soluble salts compared to Werer site. However, in all four sites, the soil is normal soil. Available Phosphorus in all sites is high. Likewise, the organic matter (OM) is relatively high in Gewane and 
Bedul-ale (Table 2). Additionally, Total nitrogen has shown the increasing tendency at harvest for the first treatment $\left(46 \mathrm{~kg} \mathrm{ha}^{-1} \mathrm{~N}\right)$ than the control across all experimental sites; which might be due to the application of $\mathrm{N}$ fertilizer.

Table 2: The soil chemical properties before sowing and after harvest

\begin{tabular}{|c|c|c|c|c|c|c|c|c|}
\hline Location & Sampling time & Treatment & $\mathrm{pH}$ & $\begin{array}{c}\text { EC } \\
(\mathrm{dS} / \mathrm{m})\end{array}$ & $\mathrm{K}(\mathrm{ppm})$ & $\begin{array}{l}\text { Avail. P } \\
(\mathrm{mg} / \mathrm{kg})\end{array}$ & $\mathrm{OM}(\%)$ & $\mathrm{TN}(\%)$ \\
\hline \multirow{2}{*}{ Werer } & Before planting & composite & 7.48 & 0.65 & 1.57 & 26.30 & 1.91 & 0.073 \\
\hline & After harvest & $\begin{array}{l}46 \mathrm{~kg} \mathrm{ha}^{-1} \\
0 \mathrm{Kg} \mathrm{ha}^{-1}\end{array}$ & $\begin{array}{c}7.2 \\
8.08 \\
\end{array}$ & $\begin{array}{c}0.6 \\
0.87\end{array}$ & $\begin{array}{l}5.31 \\
4.21 \\
\end{array}$ & $\begin{array}{l}20.70 \\
20.20 \\
\end{array}$ & $\begin{array}{l}1.53 \\
1.65 \\
\end{array}$ & $\begin{array}{c}0.107 \\
0.07 \\
\end{array}$ \\
\hline \multirow{2}{*}{ Bedul-ale } & Before planting & composite & 8.02 & 0.78 & 7.26 & 25.90 & 2.19 & 0.08 \\
\hline & After harvest & $\begin{array}{l}46 \mathrm{~kg} \mathrm{ha}^{-1} \\
0 \mathrm{Kg} \mathrm{ha}^{-1}\end{array}$ & $\begin{array}{l}7.83 \\
8.19 \\
\end{array}$ & $\begin{array}{l}0.55 \\
0.76\end{array}$ & $\begin{array}{l}5.23 \\
3.21 \\
\end{array}$ & $\begin{array}{l}23.10 \\
22.40\end{array}$ & $\begin{array}{l}2.02 \\
1.44\end{array}$ & $\begin{array}{l}0.12 \\
0.10\end{array}$ \\
\hline \multirow{2}{*}{ Bedehamo } & Before planting & composite & 8.23 & 0.89 & 6.43 & 24.2 & 2.2 & 0.01 \\
\hline & After harvest & $\begin{array}{l}46 \mathrm{~kg} \mathrm{ha}^{-1} \\
0 \mathrm{Kg} \mathrm{ha}^{-1}\end{array}$ & $\begin{array}{l}7.87 \\
8.01 \\
\end{array}$ & $\begin{array}{l}0.71 \\
1.78 \\
\end{array}$ & $\begin{array}{l}5.43 \\
14.39 \\
\end{array}$ & $\begin{array}{l}19.10 \\
27.20 \\
\end{array}$ & $\begin{array}{l}1.47 \\
1.40 \\
\end{array}$ & $\begin{array}{l}0.11 \\
0.09 \\
\end{array}$ \\
\hline \multirow{2}{*}{ Gewane } & Before planting & composite & 8.24 & 0.97 & 7.26 & 25.9 & 2.39 & 0.08 \\
\hline & After harvest & $\begin{array}{l}46 \mathrm{~kg} \mathrm{ha}^{-1} \\
0 \mathrm{Kg} \mathrm{ha}^{-1}\end{array}$ & $\begin{array}{l}7.74 \\
8.12 \\
\end{array}$ & $\begin{array}{l}0.81 \\
0.90\end{array}$ & $\begin{array}{l}3.79 \\
5.23 \\
\end{array}$ & $\begin{array}{l}21.5 \\
37.1\end{array}$ & $\begin{array}{l}1.71 \\
1.53\end{array}$ & $\begin{array}{l}0.14 \\
0.01 \\
\end{array}$ \\
\hline
\end{tabular}

*Notes: pH is potential of Hydrogen, EC (dS/m) is Electrical conductivity, $\mathbf{K}(\mathrm{ppm})$ is soluble potassium, Avail. $\mathbf{P}(\mathrm{mg} / \mathrm{kg})$ is available phosphorus, $\mathbf{O M}(\%)$ is Organic matter and TN $(\%)$ is Total nitrogen.

\subsection{Plant height and seed-cotton yield}

Analysis of variance for combined data over years and locations of the parameters recorded were indicated in Table 3. The plant height was significantly influenced by locations and also the interaction effects of year-location were significant (Table 3). In terms of seed-cotton yield, significant difference was observed due to the effects of locations and treatment applied. Similarly, the interaction effect of year by location, location by treatment interaction, and the three way (year by location by treatment) were significant for seed cotton yield. However, the other two-way interaction of year by treatment; as well as the main effect of years was non-significant for all the parameters (Table 3).

Table 3: The plant height and seed cotton yield as influenced by fertilizer levels over locations and years

Source Parameters

\begin{tabular}{llc} 
& Plant height $(\mathrm{cm})$ & Seed Cotton Yield (Ton /ha) \\
\hline Year & Ns & Ns \\
Location & $* *$ & Ns \\
Replication & Ns & $* * *$ \\
Treatment & Ns & $* *$ \\
Year Location & $*$ & Ns \\
Year*Treatment & Ns & $* *$ \\
Location*Treatment & Ns & $*$ \\
Year*Location*Treatment & Ns & $*$ \\
\hline
\end{tabular}

$*, * *,=$ show significance at 5 and $1 \%$ probability levels respectively, Ns =Non-significant.

A Significantly higher value of plant height was recorded at Gewane district. In terms of seed-cotton yield, a significantly higher yield was recorded at Werer and Bedehamo sites. Highly significant differences also observed due to the application of different treatments on seed cotton yields (Table 4). The higher seed cotton yield of (2.89 ton $\mathrm{ha}^{-1}$ ) was found at $46 \mathrm{~kg} \mathrm{ha}^{-1}$ nitrogen fertilizer. On average, it has increases $68 \%$ seed cotton yield over farmer's practice. This result agreed with the previous findings of Ayissaa and Kebede (2011), in which greater seed cotton yield of 5.39 ton $\mathrm{ha}^{-1}$ was reported at $46 \mathrm{~kg} \mathrm{ha}^{-1}$ of nitrogen fertilizer level at Werer Agricultural Research Center. Additionally, it confirmed the finding of Adugna et al. (2016), in which 4.42 ton ha ${ }^{-1}$ of seedcotton yield was reported at the nitrogen fertilizer level of $46 \mathrm{~kg} \mathrm{ha}^{-1}$ as the best recommendation from economics point of views. However, both previous findings exceed the yield potential of Deltapine-90 (3.86 ton ha $\left.{ }^{-1}\right)$, reported by Gudeta and G.Egziabher (2019), at irrigation condition of Amibara areas, Werer Agricultural Research Center. Whereas, the current finding is lower than the yield potential of the stated variety Deltapine-90 at the same agro- 
ecology. This might be relative to the time of previous studies conducted. Currently the soil productivity in the area declined and soil salinity also aggravated due to miss management of irrigation water.

Table 4: Effects of nitrogen fertilizer application on plant height and seed-cotton yield at Werer Agricultural Research center, Bedul-ale, Bedehamo and Gewane locations during 2017 and 2018

\begin{tabular}{lcc}
\hline Factors & \multicolumn{2}{c}{ Parameters } \\
\cline { 2 - 3 } \multicolumn{1}{c}{ Year } & Plant height $(\mathrm{cm})$ & Seed-Cotton Yield (Ton ha $\left.{ }^{-1}\right)$ \\
2017 & 82.02 & 2.33 \\
2018 & 82.18 & 2.26 \\
\hline Location & $73.43^{\mathrm{b}}$ & $2.50^{\mathrm{a}}$ \\
Werer research center & $79.57^{\mathrm{b}}$ & $2.10^{\mathrm{b}}$ \\
Bedul-ale & $79.89^{\mathrm{b}}$ & $2.45^{\mathrm{a}}$ \\
Bedehamo & $95.52^{\mathrm{a}}$ & $2.17^{\mathrm{b}}$ \\
Gewane & 13.44 & 0.14 \\
\hline LSD $(\mathrm{P}=0.05)$ & & \\
Fertilizer level & 82.99 & $2.89^{\mathrm{a}}$ \\
46 kg ha ${ }^{-1}$ & 81.2 & $1.72^{\mathrm{b}}$ \\
No fertilizer & & 7.46 \\
$C V$ & & 0.10
\end{tabular}

Means with the same letter in each column are not significantly different at $(\alpha=0.05)$

\section{Conclusion}

The result of this experiment has validated the previous findings on similar agro-ecology and soil type at the recommended rate of nitrogen fertilizer $\left(46 \mathrm{~kg} \mathrm{ha}^{-1}\right)$ for cotton production; which gave a significantly higher mean seed-cotton yield of 2.89 ton $\mathrm{ha}^{-1}$ over the farmer practice (without fertilizer) 1.72 ton ha ${ }^{-1}$ showing its promising for future use in the region, particularly in middle Awash.

\section{References}

Abebe, M., 1982. investigation into the cause of wilt in cotton. In Cotton production under irrigation in Ethiopia: proceedings of the symposium. Addis Abeba, Ethiopia: Institute of Agricultural Research, 1982..

Adugna, G., Nida, H., Mnalku, A., Amsalu, S. and Mnaleshewa, M., 2015. A Review of Soil Fertility Improvement and Monitoring Studies on Cotton at Middle Awash and Arbaminch Areas, Ethiopia. Academic Research Journal of Agricultural Science and Research, 4(1), pp.18-30.

Ayissaa, T. and Kebedeb, F., 2011. Effect of nitrogenous fertilizer on the growth and yield of cotton (Gossypium hirsutum L.) varieties in Middle Awash, Ethiopia. J Drylands, 4, pp.248-258.

Bremner, J.M., 1996. Nitrogen-total. Methods of Soil Analysis: Part 3 Chemical Methods, 5, pp.1085-1121.

EIA (Ethiopian Investment Agency). (2012). Investment opportunity profile for cotton production and ginning In Ethiopia. Updated Report on Cotton Ginning. Addis Ababa, Ethiopia.

Garic, R., 1989. The efficacy of some new systemic fungicides in controlling Venturia inaequalis and Podosphaera leucotricha. Pesticidi (Yugoslavia).

Gudeta, B. and Egziabher, A.G., 2019. Cotton production potential areas, production trends, research status, gaps and future directions of cotton improvement in Ethiopia.

McConnell, J.S., Baker, W.H. and Frizzell, B.S., 1996. Distribution of residual nitrate-nitrogen in long-term fertilization studies of an Alfisol cropped to cotton. Journal of environmental quality, 25(6): 1389-1394.

Menaleshoa, M., Worku, A., Chekol, W. and Tadesse, G., 2016. Effect of Long-Term Continuous Cotton MonoCropping on Depletion of Soil NPK and Changes in Some Selected Soil Chemical Characters on Vertisols and Fluvisols. Agriculture, Forestry and Fisheries, 5(5), pp.163-169.

Olsen, S.R., Cole, C. V., Watanabe, F.S. and Dean, L.A. 1954. Estimation of available phosphorus in soils by extraction with sodium bicarbonate. U.S. Dep. of Agric. Circ. 939.

Peech, M. 1986. Hydrogen ion activity. pp. 914-925. In: Methods of Soil Analysis. Part 2. Chemical and Microbiological Properties. Agronomy Monograph 9.

Roy, R.N., Finck, A., Blair, G.J. and Tandon, H.L.S., 2006. Nutrient management guidelines for some major field crops. Plant nutrition for food security. A guide for integrated nutrient management. FAO, Rome, pp.235349.

Saleem, M.F., Bilal, M.F., Awais, M., Shahid, M.Q. and Anjum, S.A., 2010. Effect of nitrogen on seed cotton yield and fiber qualities of cotton (Gossypium hirsutum L.) cultivars. Journal of Animal \& Plant Science, 20, pp.23-27.

SAS, 2003. Statistical analysis system: version 9.0, SAS Institute Inc, Cary, North Carolina, USA. 
Walkley, A. and Black, I.A. 1934. An examination of the Degtjareff method for determining soil organic matter, and a proposed modification of the chromic soil titration method. Soil Sci. 37: 29-38.

Worku, A. and Bedadi, B., 2016. Studies on soil physical properties of salt affected soil in Amibara area, central rift valley of Ethiopia. International Journal of Agricultural Sciences and Natural Resources, 3(2), pp.8-17. 